\title{
A Comparative Study between Nitroglycerin and Magnesium Sulfate during Shoulder Arthroscopic Surgery in the Beach Chair Position
}

\author{
AMIRA A. AWAD, M.D.* and MOHAMED N. AHMED, M.Sc.** \\ The Departments of Anesthesia \& Intensive Care* and Orthopedic Surgery**, Faculty of Medicine for Girls, \\ Al-Azhar University, Egypt
}

\begin{abstract}
Background: This study was designed to compare the efficacy of intravenous infusion of nitroglycerin versus magnesium sulfate for controlled hypotensive anesthesia during arthroscopic shoulder surgery in Beach Chair Position (BCP).

Aim of Study: To compare the efficacy of nitroglycerin versus magnesium sulfate in inducing deliberate hypotension and satisfactory surgical field in patients undergoing arthroscopic shoulder surgery.
\end{abstract}

Material and Methods: Fourty patients scheduled for arthroscopic shoulder surgery under general anesthesia in $\mathrm{BCP}$, randomly assigned into two equal groups, nitroglycerin group (NTG group, $\mathrm{n}=20$ ) received infusion of $0.5-5 \mu \mathrm{g} / \mathrm{kg} / \mathrm{min}$ and magnesium group ( $\mathrm{Mg}$ group, $\mathrm{n}=20$ ) received $40 \mathrm{mg} / \mathrm{kg}$, as slow bolus before induction in $100 \mathrm{~mL}$ saline solution over $10 \mathrm{~min}$ then $15 \mathrm{mg} / \mathrm{kg} / \mathrm{h}$ by infusion during the operation to achieve a mean arterial blood pressure (MAP) of about 50 to $65 \mathrm{mmHg}$.

Results: Controlled hypotension was achieved in both groups. There was no significant difference in MAP between two groups in first 30mins after infusion then magniseum group produced significantly lower MAP values till stopping of infusion. Heart Rate (HR) was significantly lower in mg group compared with the NTG group. More patients required fentanyl consumption intraoperative $(p<0.0001)$ and frequent administration of rocuronium ( $p=0.001)$ in NTG group. However, there was longer extubation time and recovery time in Mg group compared with the NTG group. Bleeding score was insignificantly lower in $\mathrm{Mg}$ group and surgeon's satisfaction score was significantly better $(p=0.035)$ in the $\mathrm{Mg}$ group.

Conclusions: Nitroglycerin and magnesium sulfate can effective in achieving hypotensive anesthesia during arthroscopic shoulder surgery. However, $\mathrm{MgSO} 4$ provide a favorable surgical field condition and better surgeon's satisfaction.

Correspondence to: Dr. Amira A. Awad, The Department of Anesthesia \& Intensive Care, Faculty of Medicine for Girls, Al-Azhar University, Egypt
Key Words: Controlled hypotension - Nitroglycerin - Magnesium sulfate - General anesthesia - Beach chair position - Arthroscopic shoulder surgery.

\section{Introduction}

SHOULDER arthroscopy is a minimally invasive technique used for diagnostic and therapeutic indications. It is associated with benefits such as lesser post-operative pain and early rehabilitation as compared to open techniques [1]. Shoulder arthroscopy has some complications related to beach chair position, use of irrigation fluid and patient positioning, these complications can be managed by early detection and prevention [2,3]. The Beach Chair Position (BCP) facilitates the approach to the shoulder joint and improves visualization, marked physiological change occurs when an anesthetized patient is tilted from a supine to upright position [4]. Gravity causes blood to pool into the lower extremities and a shift in intrathoracic blood volume to the extrathoracic space so venous return is decreased resulting in a significant decrease in cardiac output, systemic vascular resistance and arterial pressure [5,6]. Also, this position increases the risk hypoperfusion of the brain due to reduce cerebral perfusion and oxygenation and produce neurologic complications [7].

Controlled hypotension is a technique to decrease arterial blood pressure in a controllable manner to minimize the intraoperative bleeding and improve the quality of surgical field aims to lower the mean arterial blood pressure to values between 50 and $65 \mathrm{mmHg}$. However (BCP) and hypotension, may have the risk to cause postoperative neurological insults, so cerebral oximetry is important to evaluate cerebral ischemia $[8,9]$. 
Nitroglycerin (NTG), is a direct acting peripheral vasodilator and it is frequently used to produce controlled hypotension as it has rapid onset of action, rapid offset action, and titrability. However the disadvantages of nitroglycerine are reflex tachycardia and venous congestion leading to increased blood loss [10]

Magnesium sulfate is a noncompetitive antagonist of N-methyl-daspartatereceptors, magnesium can cause hypotension through a vasodilator effect. The vasodilator effect caused by increased synthesis of prostacyclin, inhibition of angiotensin-converting enzymes and has an analgesic effect. $\mathrm{Mg}++$ is important for the release of acetylcholine from presynaptic terminals and inhibits the release of norepinephrine by blocking the $\mathrm{N}$-type $\mathrm{Ca}++$ channels at nerve endings and thus decrease the blood pressure [11,12].

\section{Patients and Methods}

Fourty patients of both sex with ASA physical status (American society of anesthesiologists) classes I-II, aged 21-50 years scheduled for arthroscopic shoulder surgery in the BCP were randomly assigned into two groups contains 20 patients according to hypotensive agent during the surgery: Nitroglycerine and Magnesium sulfate groups by computer-generated random numbers. A written informed consent was obtained from all patients. The enrollment period lasted from February 2018 to May 2019 in Al-Azhar University Hospital, Egypt. Exclusion criteria included patients who had hypertension, ischaemic heart disease, hepatic and renal disorders and cerebral impairment, patients with known coagulopathies or history of allergy to the study drugs.

After arrival the patients to the operating room, intravenous cannula was inserted and the two groups were monitored by standard monitoring (noninvasive blood pressure, Electrocardiography (ECG) and peripheral oxygen saturation $\left(\mathrm{SpO}_{2}\right)$ then all patients were premedicated with 0.03-0.05 $\mathrm{mg} / \mathrm{kg}$ midazolam.

All patients were given a general anesthesia, after pre-oxygenation, anesthesia was induced with fentanyl $1-2 \mathrm{pg} / \mathrm{kg}$ and propofol $1-2 \mathrm{mg} / \mathrm{kg}$, rocuronium $0.6-0.8 \mathrm{mg} / \mathrm{kg}$ was used for intubation and muscle relaxation, intubation was performed with armored tracheal tube. Maintenance of anesthesia was achieved with a mixture of oxygen, air (1:1), sevoflurane at $1-2 \%$ minimum alveolar anesthetic concentration (MAC) and intermittent boluses of rocuronium was given $0.1 \mathrm{mg} / \mathrm{kg}$ if required. Ventilation was controlled to maintain end-tidal carbon dioxide $\left(\mathrm{EtCO}_{2}\right)$ between $35-40 \mathrm{mmHg}$. Intraoperative fluid administration was $6-8 \mathrm{ml} / \mathrm{kg} / \mathrm{h}$ of ringer solution.

After anesthesia induction, another cannula was inserted for infusion of study drugs. Then the head was secured in neutral position and fixed with a mayfield head holder to ensure that cerebral venous drainage was not impaired. The back of the operating room table was raised to 65-75 above the horizontal plane to put the patient into a beachchair table (BCP). Knees were slightly flexed over a pillow.

Nitroglycerine (NTG group): Patients were given normal saline $100 \mathrm{ml}$ I.V bolus over $10 \mathrm{mins}$ before induction of anesthesia (placebo) followed by infusion of nitroglycerine $0.5-5 \mathrm{pg} / \mathrm{kg} / \mathrm{min}$, prepared by put one ampoules of nitroglycerine (Nitronal ampoule 50mg in 50ml, Sunny pharmaceutical, Egypt) in $50 \mathrm{ml}$ syringe $(1 \mathrm{mg} / \mathrm{ml})$ according to the patients desired target blood pressure immediately started after BCP position.

Magnesium sulfate (Mg group): Patients received I.V bolus of magnesium sulfate $40 \mathrm{mg} / \mathrm{kg}$ in a $100 \mathrm{ml}$ normal saline over $10 \mathrm{mins}$ before induction of anesthesia followed by infusion of 15 $\mathrm{mg} / \mathrm{kg} / \mathrm{h}$ (magnesium sulfate ampoule $1000 \mathrm{mg}$ in $10 \mathrm{ml}$, EIPICO, Egypt) prepared in $50 \mathrm{ml}$ syringe $(100 \mathrm{mg} / \mathrm{ml})$ started after BCP position until the end of surgery.

Drugs prepared in identical syringes before operation by an anesthesiologist (anesthesia resident) who had no rule in the study, the intraoperative monitoring was done by anesthesiologist who will be administering the drug but unaware of the content of the syringes.

Patients with hypotension (reduction $<20 \%$ of baseline MAP or less than $50 \mathrm{mmHg}$ ) were treated by discontinuation of the hypotensive agent, fluid therapy and reducing the concentration of sevoflurane. If the MAP did not improve, 5-10mg ephedrine was given $\&$ these patients were excluded from the study. Patient developing bradycardia (HR <50bpm) were managed by atropine and if tachycardia (HR > 100bpm) occurred, fentanyl $50 \mathrm{pg}$ was given. HR and MAP were recorded before induction of anesthesia (basal), after induction of anesthesia, 5 minutes after BCP, 5 minutes after infusion then every 5 minutes after BCP till $60 \mathrm{~min}$ from the start of hypotensive infusion and $10 \mathrm{~min}$ after discontinuing the hypotensive agent 
(end of surgery) and after change from BCP to supine position. At the end of surgery sevoflurane was switched off, then neostigmine $0.05 \mathrm{mg} / \mathrm{kg}$ plus atropine $0.01 \mathrm{mg} / \mathrm{kg}$ was given in order to antagonize the neuromuscular block. All patients were extubated fully awake in the operating room, $\mathrm{HR}$ and MAP were recorded after extubation of the patient. The time between discontinuation of anesthesia and extubation (extubation time) and time from extubation until patients ready to transfer to the ward (recovery time) both times were recorded in two groups by an anesthetist who was 'blind' in terms of patient groups. Surgical field was assessed by the same surgeon in terms of bleeding and visibility using a 6-option liker-scale; $0=$ no bleeding; $1=$ minor bleeding, no aspiration required; $2=$ minor bleeding, aspiration required; $3=$ minor bleeding, frequent aspiration required; $4=$ moderate bleeding, visible only with the aspiration and; $5=$ severe bleeding, continuous aspiration required, very hard to perform surgery. Surgeon's satisfaction with the operative field was also evaluated using a 4-option likert scale at the end of surgery, scale: $1=$ bad, $2=$ moderate, $3=$ good, $4=$ excellent.

\section{Statistical analysis:}

Statistical analysis data were statistically described in terms of mean Standard Deviation (SD), median and range, or frequencies (number of cases) and percentages when appropriate. Comparison of numerical variables between the study groups was done using student $t$-test for independent samples. For comparing categorical data, Chi-square (2) test was performed. Exact test was used instead when the expected frequency is less than $5 . p$-values less than 0.05 was considered statistically significant. All statistical calculations were done using computer program IBM SPSS (Statistical Package for the Social Science; IBM Corp, Armonk, NY, USA) release 22 for Microsoft Windows.

\section{Results}

A total of 40 patients were enrolled in this study undergoing shoulder arthroscopic surgery were included (NTG group: $n=20, M g$ group: $n=20$ ). All patients surgeries were performed by the same surgeon. Two patients were excluded from the study as a result of severe hypotension that needs vasopressor.

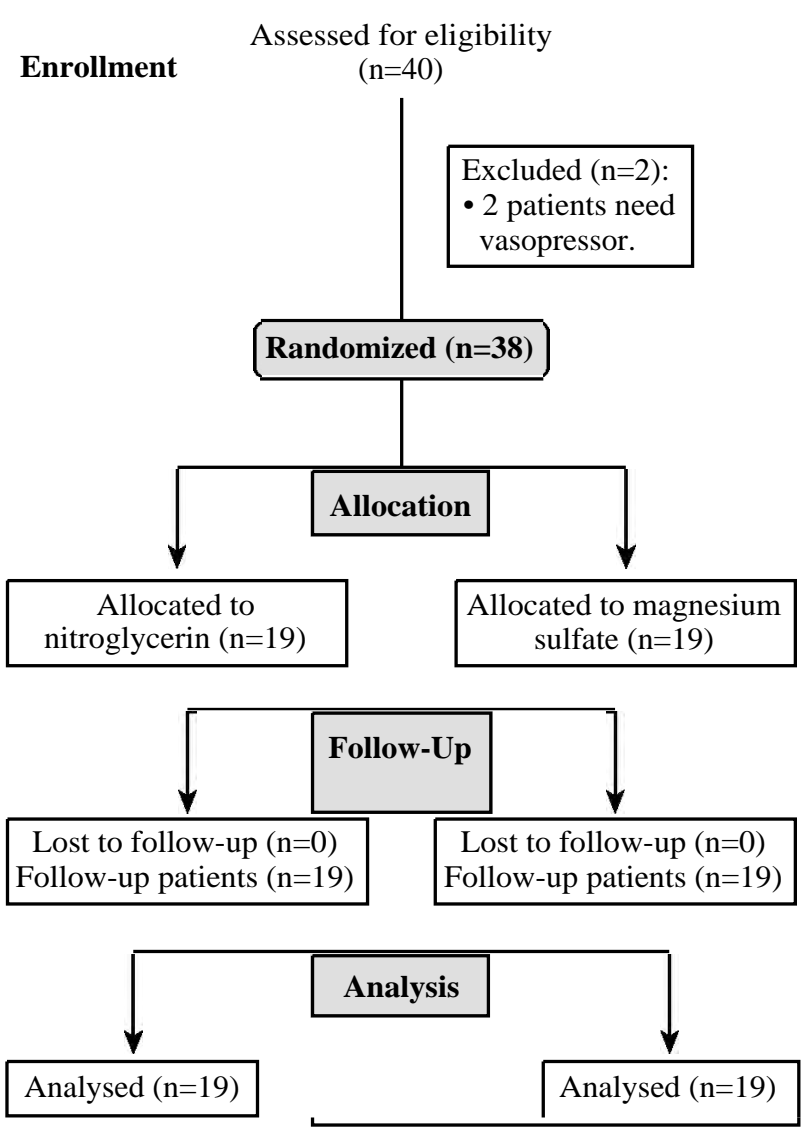

Fig. (1): Flow chart of subjects enrollment, allocation and analysis.

There were no significant differences between the two groups as regard demographic variables (age, sex, ASA, weight, height and duration of operation) which presented in (Table 1).

Table (1): Demographic data in both groups.

\begin{tabular}{|c|c|c|c|c|}
\hline & $\begin{array}{l}\text { NTG group } \\
(\mathrm{n}=19)\end{array}$ & $\begin{array}{l}\text { Mg group } \\
(\mathrm{n}=19)\end{array}$ & $\begin{array}{c}\text { Test } \\
\text { value }\end{array}$ & $\begin{array}{c}p- \\
\text { value }\end{array}$ \\
\hline $\begin{array}{l}\text { Age (years): } \\
\quad \text { Mean } \pm \text { SD }\end{array}$ & $39.1 \pm 12.15$ & $40.95 \pm 9.65$ & 0.520 & 0.606 \\
\hline $\begin{array}{c}\text { ASA: } \\
\text { I } \\
\text { II }\end{array}$ & $\begin{array}{l}14(73.7 \%) \\
5 \quad(26.3 \%)\end{array}$ & $\begin{array}{l}15(78.9 \%) \\
4 \quad(21.1 \%)\end{array}$ & 0.146 & 0.702 \\
\hline $\begin{array}{c}\operatorname{Sex}(F / M): \\
\text { Females } \\
\text { Males }\end{array}$ & $\begin{array}{l}9 \quad(47.4 \%) \\
10(52.6 \%)\end{array}$ & $\begin{array}{l}10(52.6 \%) \\
9 \quad(47.4 \%)\end{array}$ & 0.105 & 0.746 \\
\hline $\begin{array}{l}\text { Weight }(\mathrm{kg}): \\
\quad \text { Mean } \pm \mathrm{SD}\end{array}$ & $98 \pm 10.22$ & $95 \pm 23.21$ & -0.516 & 0.609 \\
\hline $\begin{array}{l}\text { Height }(\mathrm{cm}): \\
\quad \text { Mean } \pm \mathrm{SD}\end{array}$ & $161.10 \pm 10.13$ & $160 \pm 4.72$ & -0.429 & 0.671 \\
\hline $\begin{array}{l}\text { Surgical duration (min): } \\
\quad \text { Mean } \pm \text { SD }\end{array}$ & $69.4 \pm 10.5$ & $72 \pm 17.3$ & 0.560 & 0.579 \\
\hline
\end{tabular}


Heart Rate (HR) variations were presented in Fig. (2), there was increased significantly of heart rate after intubation and sitting position $(p<0.01)$ then showed significant reduction in $\mathrm{HR}$ in the $\mathrm{Mg}$ group compared to NTG group through out the operation.

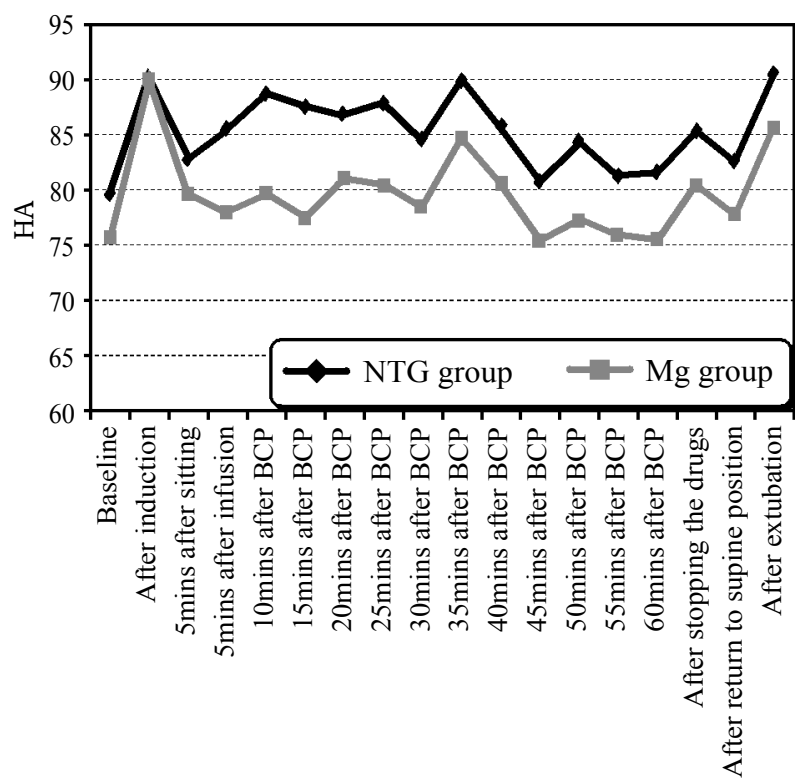

Fig. (2): Comparison between the two groups regarding HR.

MAP variations were presented in Fig. (3), MAP was decreased by two groups and reached to target value $(50-65 \mathrm{mmHg})$ after starting hypotensive infusion, MAP values were comparable between the two groups at first $30 \mathrm{~min}$ without significant difference then the MAP was significantly lower in mg group compared to NTG group. After discontinuing hypotensive infusion, MAP increased significantly in the NTG group compared with mg group.

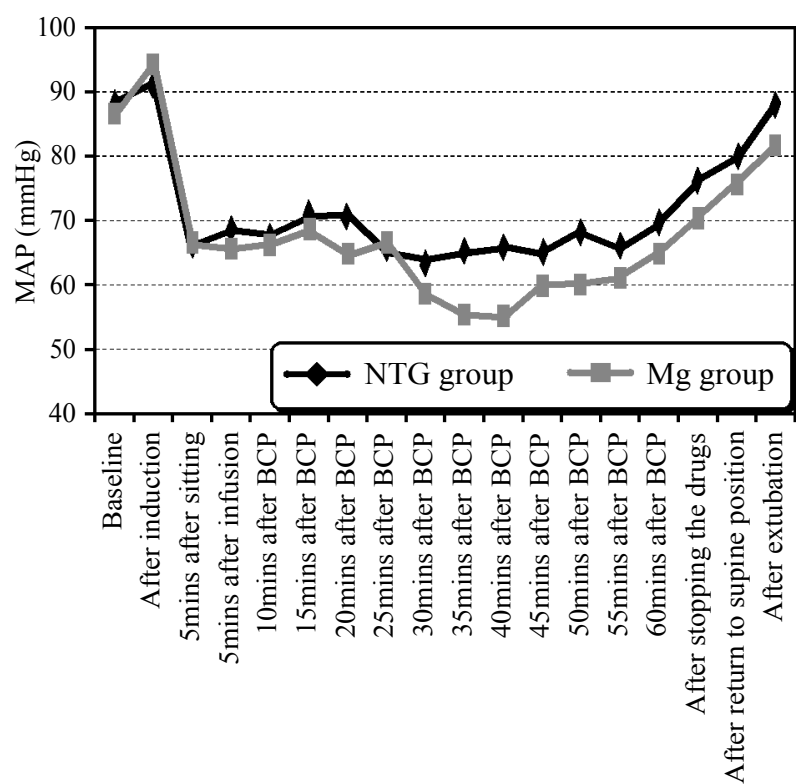

Fig. (3): Comparison between the two groups regarding MAP.
The total dose of fentanyl ( $\mathrm{s} / \mathrm{k}$ ) and rocuronium (mg) consumtion were significantly lower in group $\mathrm{Mg}$ compared to NTG group (1.05 \pm 0.09 , $50.8 \pm 12.3$ versus $1.37 \pm 0.12,66.7 \pm 14.4)$ respectively.

Extubation time and recovery time were significantly longer in the $\mathrm{Mg}$ group compared with the NTG group.

Table (2): Comparison between the two groups regarding operative and recovery data.

\begin{tabular}{lllll}
\hline & NTG & Mg & $\begin{array}{r}\text { Test } \\
\text { value }\end{array}$ & $\begin{array}{c}p- \\
\text { value }\end{array}$ \\
\hline Fentanyl requirement (ug/kg) & $1.37 \pm 0.12$ & $1.05 \pm 0.09$ & -9.299 & 0.0001 \\
Total rocuronium dose (mg) & $66.7 \pm 14.4$ & $50.8 \pm 12.3$ & -3.660 & 0.001 \\
Extubation time (min) & $5.5 \pm 2.3$ & $8.0 \pm 2.1$ & 3.499 & 0.001 \\
Recovery time (min) & $8.2 \pm 2.5$ & $10.5 \pm 3.3$ & 2.422 & 0.021 \\
\hline
\end{tabular}

The Average Category Scale (ACS) for the assessment of intraoperative bleeding presented in (Table 3), Fig. (4). Bleeding score was insignificantly decreased in mg group but surgeon satisfaction was significantly lower in NTG group (Table 4), Fig. (5).

Table (3): Comparison between the two groups regarding bleeding score.

\begin{tabular}{|c|c|c|c|c|}
\hline $\begin{array}{l}\text { Bleeding score } \\
(\mathrm{n} ; \%)\end{array}$ & $\begin{array}{l}\text { NTG } \\
(n=19)\end{array}$ & $\underset{(n=19)}{M g}$ & $\begin{array}{c}\text { Test } \\
\text { value }\end{array}$ & $\begin{array}{c}p- \\
\text { value }\end{array}$ \\
\hline 0 (no bleeding) & $0 \quad(0.0 \%)$ & $0 \quad(0.0 \%)$ & 2.232 & 0.328 \\
\hline 1 & $15(78.9 \%)$ & $16(84.2 \%)$ & & \\
\hline 2 & $2 \quad(10.5 \%)$ & $3 \quad(15.8 \%)$ & & \\
\hline 3 & $2 \quad(10.5 \%)$ & $0 \quad(0.0 \%)$ & & \\
\hline 4 & $0 \quad(0.0 \%)$ & $0 \quad(0.0 \%)$ & & \\
\hline 5 & $0 \quad(0.0 \%)$ & $0 \quad(0.0 \%)$ & & \\
\hline
\end{tabular}

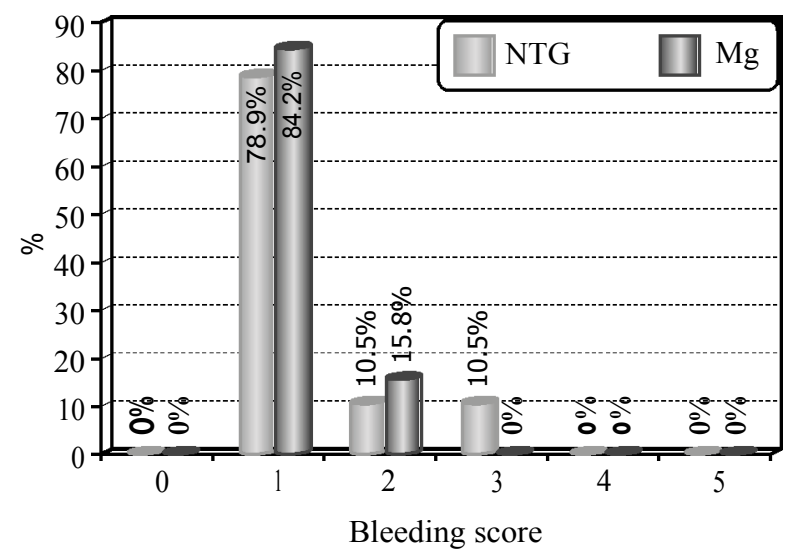

Fig. (4): Comparison between the two groups regarding bleeding score. 
Table (4): Comparison between the two groups regarding surgeon's satisfaction score.

\begin{tabular}{lcccc}
\hline $\begin{array}{l}\text { Surgeon's satisfaction } \\
\text { score }(\mathrm{n} ; \%)\end{array}$ & $\begin{array}{c}\mathrm{Mg} \\
(\mathrm{n}=19)\end{array}$ & $\begin{array}{c}\mathrm{NTG} \\
(\mathrm{n}=19)\end{array}$ & $\begin{array}{r}\text { Test } \\
\text { value }\end{array}$ & $\begin{array}{c}p \text { - } \\
\text { value }\end{array}$ \\
\hline 1 (poor) & $0(0.0 \%)$ & $0(0.0 \%)$ & 8.581 & 0.035 \\
2 (moderate) & $7(36.8 \%)$ & $0(0.0 \%)$ & & \\
3 (good) & $7(36.8 \%)$ & $11(57.9 \%)$ & & \\
4 (very good) & $5(26.3 \%)$ & $8(42.1 \%)$ & & \\
\hline
\end{tabular}

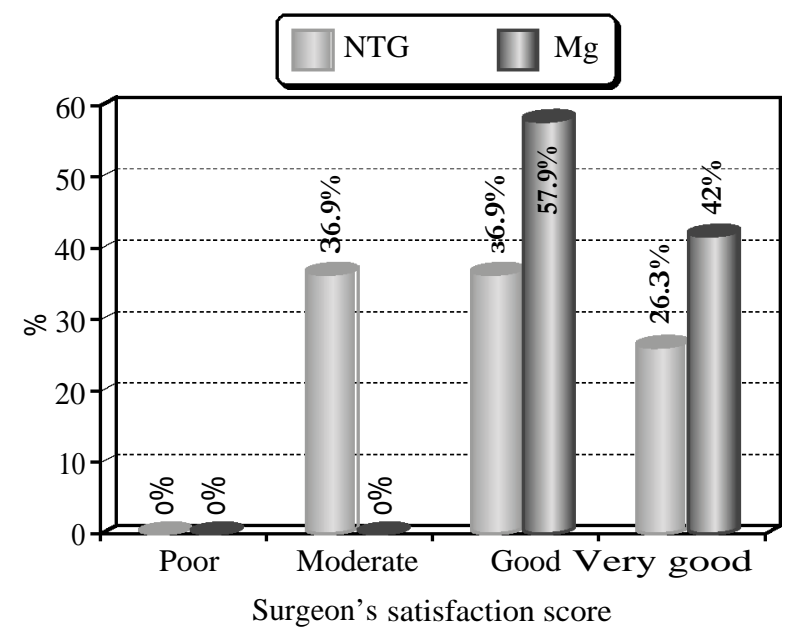

Fig. (5): Comparison between the two groups regarding surgeon's satisfaction score.

\section{Discussion}

Deliberate hypotension is widely used by anesthesiologists to decrease intraoperative blood loss and produce good surgical fields excessive bleeding prolongs the duration of surgery and anesthesia [13,14]

This randomized study designed to compare the efficacy of controlled hypotensive anesthesia with intravenous infusion of nitroglycerine versus magnesium sulfate in patients undergoing shoulder arthoscopic surgery.

NTG has direct action on vascular smooth muscles. This vasodilator effect may produced more oozing at the surgical field. NTG, produce reduction of MAP accompanied by increase in HR and rebound hypertension after stoppage of infusion [15] . Reflex tachycardia may be a contributing factor to increased surgical bleeding by increasing the cardiac output.

Magnesium Sulphate $\left(\mathrm{MgSO}_{4}\right)$ was used to induce deliberate hypotension and it produces its hypotensive effect by limiting the outflow of calcium from the sarcoplasmic reticulum and produces a vasodilation effect. Hypotension induced by magnesium is also explained by its powerful analgesic effect. The analgesic action of magnesium is explained by its antagonistic effect at $\mathrm{N}$-methyl $\mathrm{d}$-aspartate receptors $[\mathbf{1 6 , 1 7 ]}$

Till the time of conduction of study, there were no studies comparing the efficacy of these two drugs in achieving controlled hypotension in patients undergoing shoulder arthroscope.

The current study revealed that controlled hypotension was achieved in both groups despite the lower values of MAP in the Mg group and in both groups the operative field condition was comparable and surgeon satisfaction was better in magnesium group.

In the same line of the study and used both studied drugs but in functional endoscopic sinus surgery, Shoukry and Mahmoud [18] who used $\mathrm{MgSO}_{4}, 30 \mathrm{mg} / \mathrm{kg}$ intravenously over a period of $10 \mathrm{~min}$ before induction of anesthesia and 10 $\mathrm{mg} / \mathrm{kg} / \mathrm{h}$ by continuous infusion versus NTG infusion of $3-5 \mathrm{gg} / \mathrm{kg} / \mathrm{min}$ and they noticed both groups were reduced MAP to the targeted $(55-65 \mathrm{mmHg})$. In MGS group they found, there were better operative conditions, surgeon satisfaction and reduced anesthetic requirements but in current study dose of magnesium sulfate was higher and in NTG group the dose was $0.5-5 \mathrm{gg} / \mathrm{kg} / \mathrm{min}$.

There are several previous studies were in accordance with present study, but were done during different operation not in arthroscopic shoulder surgeries and revealed that nitroglycerine is a well-established simple drug produce hypotensive anesthesia when compared with other hypotensive drugs (not $\mathrm{MgSO}_{4}$ ) like Ghodraty et al., [20] compared labetalol and nitroglycerine on inducing controlled hypotension and intraoperative blood loss in rhinoplasty. MAP $(p<0.001)$ were significantly lower in the nitroglycerine group. There was no significant difference between the groups regarding the volume of bleeding $(p=0.75)$; however, the surgeons were more satisfied with nitroglycerine than labetalol $(p<0.001)$.

Nitroglycerin versus dexmedetomidine for controlled hypotensive in Functional Endoscopic Sinus Surgery (FESS), study was done by Darshna et al., [21] and used in group D, loading dose of dexmedetomidine 1 over a period of $10 \mathrm{~min}$ before induction and followed by maintenance infusion in the dose of $0.4-0.8 \mathrm{gg} / \mathrm{kg} / \mathrm{h}$ after intubation. Group $\mathrm{N}$ patients received infusion nitroglycerin $5-10 \mathrm{~g} / \mathrm{k} / \mathrm{min}$ after intub ati on. They observed significant increase in mean pulse rate in the $\mathrm{Ni}$ troglycerine group as compared to the Dexmedetomidine group. Mean arterial pressure was successfully reduced to the target value in both the groups. 
There was no difference in amount of blood loss between the two groups.

Srivastava et al., [19] they compared NTG with esmolol, and they noted that both drugs produced desired hypotension and improved surgical condition during FESS by reducing operative field bleeding but ideal operative conditions were achieved at mild hypotension (MABP 75-70) in ESM group while same conditions were achieved at MABP of $69-65 \mathrm{~mm}$ of $\mathrm{Hg}$ in NTG group. Mean heart rate was significantly higher in NTG group as compared to ESM group. Blood loss was significantly less in ESM group.

In the same line with current study, several previous studies but were not done in arthroscopic shoulder surgeries and revealed that magnesium sulfate a safe effective drug produce hypotensive anesthesia when compared with other hypotensive drugs (not nitroglycerin) as Elsharnouby and Elsharnouby [22] who used $\mathrm{MgSO} 4$ (40mg/kg) intravenously over a period of $15 \mathrm{~min}$ before induction of anesthesia and $15 \mathrm{mg} / \mathrm{kg} / \mathrm{h}$ by continuous infusion to induce hypotension during FESS. The same volume of isotonic solution was administered to the control group they noticed magnesium sulphate produced a reduction in MAP, heart rate, blood loss. Furthermore, magnesium infusion alters anaesthetic dose requirements and prolonge anaesthetic emergence time.

Ryu et al., [23] compared magnesium with remifentanil for hypotensive anesthesia during middle ear surgery. Patients received between 34 $\mathrm{ng} / \mathrm{ml}$ remifentanil using target-controlled infusion (group R) or magnesium sulphate (group M), patients received i.v. magnesium sulphate bolus of $50 \mathrm{mgkg}$ followed by $15 \mathrm{mg} / \mathrm{kg} / \mathrm{h}$ to maintain (MAP) between $60-70 \mathrm{~mm} \mathrm{Hg}$ and they found controlled hypotension was well maintained in both groups. MAP and heart rate were higher in group R than in group $M$ after operation. Surgical conditions were not different between the two groups.

Study of Rokhtabnak et al., [24] reported that a comparison of dexmedetomidine versus magnesium sulfate in controlled hypotension during rhinoplasty. Patients in group Dex, received $1 \mathrm{~g} / \mathrm{kg}$ in 10 minutes before induction of anesthesia, followed by $0.4-0.6 \mu \mathrm{g} / \mathrm{kg} /$ hour during the maintenance, and group $\mathrm{Mg}$, received $40 \mathrm{mg} / \mathrm{kg}$ in 10 minutes before induction followed by $10-15$ $\mathrm{mg} / \mathrm{kg} /$ hour during maintenance and they found no significant difference in MAP between both groups, but (HR) was significantly lower in the Dex group compared with $\mathrm{Mg}$ group. Bleeding score was lower and surgeon's satisfaction score was higher in Dex group. More patients required fentanyl or nitroglycerin in $\mathrm{Mg}$ group. Patients in Dex group required frequent administration of cisatracurium.

\section{Conclusion:}

Nitroglycerin and magnesium are safe, efficient and might be advisable option for deliberate hypotensive anesthesia. This study revealed that magnesium was more effective in performing controlled hypotension during arthroscopic shoulder surgery and provided a better surgical field and surgeon satisfaction and less tachycardia than nitroglycerin.

\section{Limitations:}

Study need to be conducted with larger sample size, further studies are recommended to evaluate the efficacy of hypotensive drugs for patients undergoing arthroscopic shoulder surgery. Peripheral nerve stimulation to monitor neuromuscular block or bispectral index to monitor depth of anesthesia were not used in this study, instead we relied on measuring the extubation and recovery times.

\section{Conflicts of interest:}

The authors declare no conflicts of interest.

\section{References}

1- American Orthopaedic Society for Sports Medicine. Arthroscopy, [Last accessed on 2015 May 22], 2008.

2- RAINS D.D., ROOKE G.A. and WAHL C.J.: Patho mechanisms and complications related to patient positioning and anesthesia during shoulder arthroscopy. Arthroscopy, 27: 532-41, 2011.

3- HEARNDEN A. and TENNENT D.: The cost ofshoulder arthroscopy: A comparison with national tariff. Ann. R. Coll. Surg. Engl., 90: 587-91, 2008.

4- PROVENCHER M.T., MCINTIRE E.S. and GASTON T.M.: Avoiding complications in shoulder arthroscopy: Pearls for lateral decubitus and beach chair positioning. Tech. Shoulder. Elbow. Surg., 11: 1-3, 2010.

5- COONAN T.J. and HOPE C.E.: Cardio-respiratory effects of change of body position. Can. Anaesth. Soc. J., 30 (4): 424-38, 1983.

6- CHAMBERS LAUCHLAN, KREMEN THOMAS SNELL CHRISTOPHER J. and GAMRADT SETH C.: Arthroscopic anterior shoulder stabilization in the beach chair position using trans-subscapularis drilling of the 5:30 anchor. Tech. Should Surg., 12: 56-61, 2011.

7- POHL A. and CULLEN D.J.: Cerebral ischemia during shoulder surgery in the upright position: A case series. J. Clin. Anesth., 17: 463-9, 2005.

8- VAN AKEN H. and MILLER D.: Delibrate hypotension. In: MillerRD, editor. Anesthesia. New York, USA: Churchill Livingstone Inc., 1470-90, 2007. 
9- MAZZON D., DANELLI G., POOLE D., MARCHINI C. and BIANCHIN C.: Beach chair position, general anesthesia and deliberated hypotension during shoulder surgery: A dangerous combination! Minerva Anestesiol. 75 (5): $281-2$.

10- SRIVASTAVA U., DUPARGUDE A.B., KUMAR D., JOSHI K. and GUPTA A.: Controlled hypotension for functional endoscopic sinus surgery: Comparison of esmolol and nitroglycerine. Indian Journal of Otolaryngology and Head \& Neck Surgery, 65: 440-4, 2013.

11- ELSHARNOUBY N.M. and ELSHARNOUBY M.M.: Magnesium sulphateas a technique of hypotensive anaesthesia. Br. J. Anaesth., 96: 727-31, 2006.

12- DUBÉ L. and GRANRY J.C.: The therapeutic use of magnesium in anesthesiology, intensive care and emergency medicine: A review. Can. J. Anesth., 50: 732-46, 2003.

13-KAMAL H.M. and ABDEL-RAHMAN A.S.H.: Clevidipne for deliberate hypotension in functional endoscopic sinus surgery (FESS). E.J.C.T.A., 2: 158-64, 2008.

14-DEGOUTE C.S.: Controlled hypotension: A guide to drug choice. Drugs, 67: 1053-76, 2007.

15- EL-SHMAA N.S., ALZEFTAWY A.E. and YOUNES A.: The Utility of Remifentanil Compared with Nitroglycerin for Deliberate Hypotensive Anaesthesia throughout Tympanoplasty. Randomized and Observer-Blinded Clinical Trial. J.C.A.O., 1: 101, 2017.

16- FRAKES M.A. and RICHARDSON L.E.: Magnesium sulfate therapy in certain emergency conditions. Am. J. Emerg. Med., 15: 182-7, 1997.

17- FUCHS-BUDER T. and TASSONYI E.: Magnesiumsulphate enhances residual neuromuscular block induced by vecuronium. Br. J. Anaesth., 76: 565-6, 1996.
18- SHOUKRY R.A. and MAHMOUD A.E.: Controlled hypotension for functional endoscopic sinus surgery: A Comparative study between magnesium sulfate and nitroglycerin. Ain-Shams Journal of Anaesthesiology, 10: 916, 2018.

19- SRIVASTAVA U., DUPARGUDE A.B., KUMAR D., JOSHI K. and GUPTA A.: Controlled hypotension for functional endoscopic sinus surgery: Comparison of esmolol and nitroglycerine. Ind. J. Otolaryngol. Head Neck Surg., 65: S440-S444, 2013.

20- GHODRATY M., KHATIBI A., ROKHTABNAK F., MALEKI M. and PARSA F.: Comparing Labetalol and Nitroglycerine on Inducing Controlled hypotension and Intraoperative Blood Loss in Rhinoplasty: A SingleBlinded Clinical Trial. Anesth. Pain Med., 7: e13677, 2017.

21- PATEL D.D., SINGH A. and UPADHYAY M.: Dexmedetomidine versus Nitroglycerin for Controlled Hypotensive Anaesthesia in Functional Endoscopic Sinus Surgery. J. Anesth. Clin. Res., 9: 5, 2018.

22- ELSHARNOUBY N.M. and ELSHARNOUBY M.M.: Magnesiumsulphate as a technique of hypotensive anaesthesia. Br. J. Anaesth., 96: 727-31, 2006.

23- RYU J.H., SOHN I.S. and DO S.H.: Controlled hypotension for middle ear surgery: A comparison between remifentanil and magnesium sulphate. Br. J. Anaesth., 103: 490-5, 2009.

24- ROKHTABNAK F., MOTLAGH S.D., GHODRATY M., POURNAJAFIAN A., DELARESTAGHI M.M., BANIHASHEMI A.T. and ARAGHI Z.: Controlled hypotension during rhinoplasty: A Comparison of dexmedetomidine with magnesium sulfate Anesth. Pain Med., 7 (6): e64032, 2017.

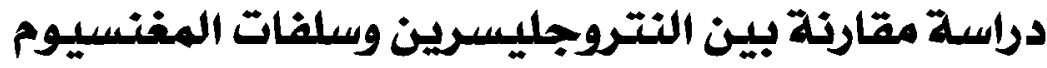

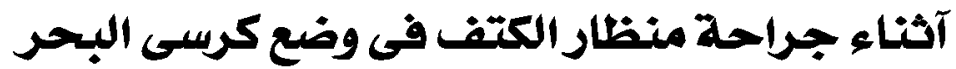

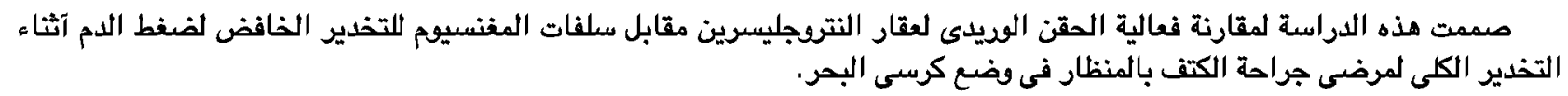

الهدف من الدراسة: الهدف من هذه الدراسة مقارنة الحقن الهريدى من النترجليسرين مقابل سلفات المغنسيوم في تقليل ضغط الدم

وتوفير حالة جراحية ملائمة آثناء جراحة الكتف بالمن هذه المنظار (BCP).

المواد والطرق: تم دراسة آربعون مريضاً من المقر إجراء لهم جراحة الكتف بالمنظار تحت التخدير العام، تم تعيينهم بشكل عشوائى

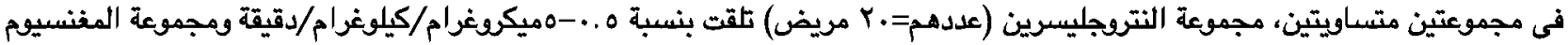

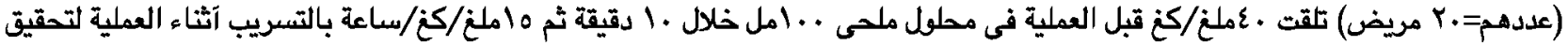

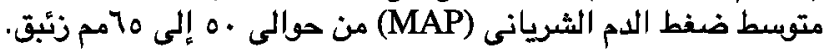

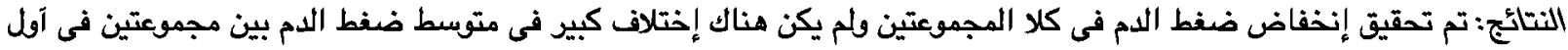

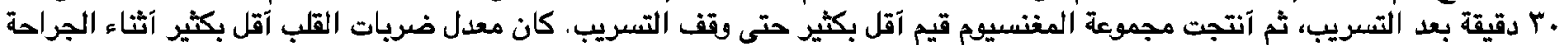

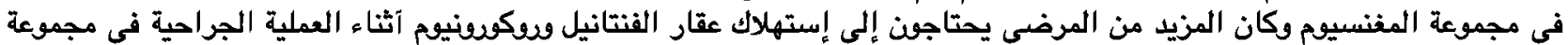

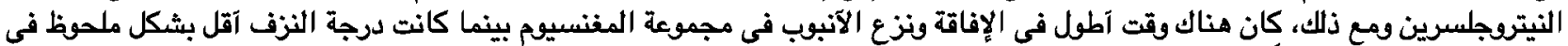

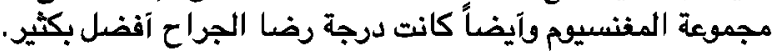

الخخلاصدة: عقار النيتروجلسرين والمغنسيوم يحققان نفس الفعالية في تحقيق التخدير الناقص لضغط الدم آثناء جراحة الكتف بالمنظار.

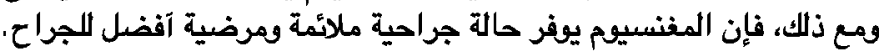

